\title{
Parent And Child Relations in The Perspective of Adolescents With Juvenile Delinquency
}

\author{
Nourmarifa Sari', Siti Rohmah Nurbayati ${ }^{2}$ \\ 1 \& 2 Department of Psychology, Faculty of Education Universitas Negeri Yogyakarta; Jl. Colombo no. 1 \\ Karang Malang, Sleman, Yogyakarta \\ nourmarifa.sari2015@student.uny.ac.id ${ }^{1}$,siti_rohmah@uny.ac.id²
}

\begin{abstract}
This study aims to determine the relationship between parents and children in the perspective of adolescents with juvenile deliquency. This study uses qualitative methods with a phenomenological approach. The research subjects were two boys aged 16-20 years who had a delinquency scale score $\geq 17$. In addition, the researcher uses the Theunnisen Delinquency Scale, as a deliquency scale, which has been translated and adjusted to the current conditions in Indonesia. As the result, it can be showed that relations according to adolescents with risky behavior were the existence of positive and negative relations. Positive relationships such as nurturing, transmitting values, closeness, attention, and togetherness. Negative relationships such as lack of support, lack of understanding, communication errors between parents and children, and conflicts that are not accompanied by good conflict management.
\end{abstract}

Keywords: parent and child relations, juvenile delinquency

\section{Introduction}

Adolescence is an individual transition period that previously children will turn into adults. As stated by Piaget (in Santrock, 2003) adolescence is the time a child interacts with other communities around him who are more mature than himself. In this period, children no longer feel at the lower levels of people who are older than themselves but are at the same level as other people.

Adolescence is also called a confusing period. Individuals who are in adolescence can no longer be referred to as children, but also cannot be referred to as adults. Individuals in this period are faced with the question of who they are, what their true potential is, and in what direction they are going in their lives. Eric Erikson (in Santrock, 2003) states that adolescents have a duty to find their own identity that best suits them. Therefore, adolescence is also referred to as the search for identity, where children prepare for their adult life.
Teenagers will gradually realize that they are responsible for themselves and their lives. Teenagers will look for what their lives will be like (Santrock, 2003). Individuals who can get through the search for self-identity are teenagers who are able to find their identity and prepare themselves well for their adult life. Many teenagers who can pass a period of self-identification search well. One example is Rebecca Alexandria who won the Youth America Grand Prix in New York, United States (Anonymous, 2018). Rebecca found herself becoming a professional ballet dancer. Another achievement was made by 4 high school students representing Indonesia in the Intel-ISEF International Research Olympiad in California, United States (Widhi, 2017). These four high school students get special awards from various institutions in America for the research they have done at this prestigious event. The examples above show that teenagers can find their identity through positive activities.

Some adolescents can pass a period of self-discovery well, but there are also 


\section{Parent Child Relation in Delinquent Adolescent Nourmarifa Sari ${ }^{1}$, Siti Rohmah Nurhayati ${ }^{2}$}

teenagers who are less able to pass through a period of self-discovery. One form of failure through the search for identity is juvenile delinquency or delinquency. Indonesian Language Dictionary (Badan Pengembangan dan Pembinaan Bahasa, 2016) describes delinquency as a behavior carried out by adolescents who violate social rules in a particular community environment. Erikson (in Santrock, 2003) states that delinquency is marked by the failure made by adolescents in achieving a situation that involves various aspects that exist in the formation of selfidentity. According to Erikson (in Santrock, 2003) also believes that adolescents who tend to go through infancy and childhood with the atmosphere or circumstances that limit them, will tend to lack the ability to meet the demands given by their environment to them, will tend to develop a negative self or the bad side of yourself.

Sutrisno (2016) in the news delivered through the republika.co.id website stated that underage children and adolescents dominate the number of perpetrators of begal in Makassar. Data of fostered citizens in Makassar IIA class prisoners (LAPAS) under the age of 18 years amounted to 96 people with diverse background cases ranging from theft, rape, to murder (Syam, 2017). This shows that the number of adolescents who commit crime in Makassar dominates.

Based on data from the Indonesian Ministry of Health in 2016 (Ministry of Health Republic of Indonesia, 2016) shows that the percentage of adolescents at the age of 16-19 years who smoke has tripled from $7.1 \%$ to $20.5 \%$ from 1995 to 2014. Data for beginner smokers at the age of 10-14 years increased by more than $100 \%$ in the time span between 1995 and 2013, ie from 8.9\% to 18\% (Andayani, 2017: 5). In 2012, teenage pregnancy rates aged 15-19 reached 48 cases out of 1,000 pregnancies (Demographic and Health Survey of Indonesia, 2013).

Various kinds of events related to delinquency can be found easily in the community. For example there were cases of molestation carried out by junior high school students in Ambon (Hutapea, 2018). The third grade junior high school student skipped school and met the victim who in fact was his girlfriend, then the perpetrator seduced the victim until the act of molestation took place. Another example that is being warmly discussed in today's society is the discovery of the corpse of an online taxi driver in a housing complex in Semarang. Based on the results of searches conducted by the police, obtained various kinds of evidence that leads to 2 students of a State Vocational School in Semarang. Both of these school students were known to deceive online taxi drivers until finally the taxi driver was killed and the suspect took a car and all valuables belonging to the victim (Assifa, 2018). In the end the police arrested both of them and made him a suspect in the murder case.

One of the factors that influence the occurrence of delinquency is the absence of the application of family support and management practices by parents (Santrock, 2003). Parents play an important role in shaping the personality and identity of adolescents. Relationships between parents and children who have been nurtured since birth properly will foster attachment (attachment) or bond relations with each other (Widiastuti \& Widjaja, 2004: 22). Dirgagunarsa \& Sutantoputri (2004) argues that parent-child relationships in normal families show a warm affection between parents and children, as well as children against parents.

Children's personalities can be shaped through parenting patterns provided by parents. Therefore, the relationship between parent and child is definitely an intimate relationship because it will not be broken up at any time. Parenting patterns and various kinds of parental responses to children will form a bond between the child and the parent as a caregiver. Various kinds of parental behavior towards children will be accepted, infused and studied by the child throughout his life. Research conducted by Muqorrobin (2016: 79) explains that parenting parents have a significant correlation with juvenile delinquency. Herdiana (2016) states that the more authoritarian parenting is done by parents, the higher the level of juvenile delinquency will also be higher. Research 
conducted by Garvin (2017: 36-37) shows that the more parents apply authoritative parenting, the lower the tendency for adolescents to become delinquent. The results of research conducted by Arif (2016: 13) show that there is a positive correlation between permissive parenting with juvenile delinquency.

Based on preliminary research conducted by researchers, obtained information three out of five children said that their parents were less able to understand and understand their desires. Their parents tend to make decisions (in matters relating to children) without considering the wishes and wishes of the child. Children say that if it really needs to be done, parents should provide a logical reason when explaining to them. This shows that there is a gap between expectations and reality in adolescents about their relationship with parents. Therefore, this problem becomes interesting to be studied more deeply about the relationship between parents and children. How do adolescents who have delinquent behavior perceives their relationship with their parents?

\section{Methods}

\section{Types of research}

This study uses a qualitative approach using phenomenology.

\section{Time and Place of Research}

This research was conducted in January to February 2019. The research was conducted in the city of Semarang.

\section{Research Respondents}

Determination of respondents in this study using a purposive sampling method, with the following inclusion criteria for the respondents:

1. Teenagers aged 16 to 20 years

2. Being in high school / equivalent

3. Has a delinquency scale score above 17, which indicates delinquent adolescents

4. Living in the city of Semarang

5. Willing to be a research respondent

\section{Procedure}

This research consists of several stages. The first stage is the researchers conducted a screening of adolescents aged 16 to 20 years who are in high school / equivalent. The second stage is the researcher introduces himself and informs the purpose of the research to the two research respondents. The third stage is the researchers conducted indepth interviews with research respondents and significant others. Interviews were conducted using interview guidelines that had been prepared. The fourth stage, the researchers conducted probing, data processing and data triangulation of research respondents.

\section{Data, Instruments and Data Collection}

The research data were obtained directly from research respondents through in-depth interviews with teenage children and biological fathers from 2 different families in Semarang. The instruments used in this study were researchers, delinquency scales, and interview guidelines. Each research respondent was interviewed approximately three times to obtain complete information.

The delinquency scale used in this study was made using the basic concept of the definition of delinquency, which is all acts committed by adolescents, where the actions are not in accordance with values and norms that can cause social anxiety and discomfort in society and can be categorized in criminal acts.

Interview guidelines were made using the concept of the relationship proposed by Fiske (1992: 690-692). However, in this study only two of the four forms of relations were used. This decision is made by considering the possible forms of relations that arise in the relationship between parent and child. The form of the relationship is Authority Ranking and Equality Matching.

Interview guidelines for parents and children in detail aim to ask the meaning of parents and children, the closeness between children and parents, and to find out the feelings of children and parents to each other. Researchers also explore information about how parenting, what values are taught by 


\section{Parent Child Relation in Delinquent Adolescent Nourmarifa Sari ${ }^{1}$, Siti Rohmah Nurhayati ${ }^{2}$}

parents to children and how they affect children. As additional information, researchers explore the forms of attention and togetherness of parents and children in order to add research data.

Other efforts by researchers to explore data or information for the sake of data richness include comparing expectations and the reality of the relationship between children and parents. The researcher also asked about the child's expectations to parents as well as the parents' expectations to the child to add information that there is a gap between expectations and reality in the relationship between parent and child. The researcher tries to ask the child's view of themselves as additional information to attract the psychological dynamics of the research respondents.

\section{Data analysis technique}

Data analysis techniques used in this study refer to the concepts put forward by Miles and Hubberman (1994), namely: Data Reduction, Data Presentation / Description, and Conclusion / Withdrawal of Conclusions (Verification).

\section{Findings and Conclusions}

Findings

\section{Relationship between parents and their children}

Researchers chose 2 teenage boys who had the highest scores based on the results of the delinquency scale used as a screening tool.

Based on the results of the analysis that has been done, the results obtained are the relationship between parents and children according to adolescents who have delinquent behavior, these forms of relations can be seen in Table 1.

Table 1. Relationship Forms

\begin{tabular}{|l|l|}
\hline Positive Relationship & Negative Relationship \\
\hline Nurturance & Lack of Support \\
\hline Value Transmission & Lack of Understanding \\
\hline Closeness & Communication Errors \\
\hline Attention & Conflicts \\
\hline Togetherness & \\
\hline
\end{tabular}

Based on Table 1, the relationship between parents and children according to adolescents who have delinquent behavior is divided into 2 forms, namely relationships that are positive, and relationships that are negative. Positive relationships consist of nurturing, value transmission, closeness, attention, and togetherness. While negative relationships consist of lack of support, lack of understanding, communication errors, and conflicts in parent and child relationships.

Discussion

One of the relationships between children and parents is care. The definition of care delivered by research respondents is consistent with the definition of care according to Brooks (2011), namely parents as individuals who care for, protect and guide children from infancy to adulthood. Parenting is also said to be a process that refers to a series of actions and interactions carried out by parents to support the child's development.

Lessons obtained by both respondents from their parents proves that in the relationship between parent and child there is a lesson that is transmitted from generation to generation. This is in accordance with the opinion expressed by Lestari (2014) that in the transmission of culture, a cultural group perpetuates the characteristics of its behavior to the next generation through teaching and learning methods (learning). 


\section{Parent Child Relation in Delinquent Adolescent Nourmarifa Sari ${ }^{1}$, Siti Rohmah Nurhayati ${ }^{2}$}

The type of attention that arises in the relationship between the respondent and his parents in the form of questions that aim to remind small activities that are carried out every day. This is in accordance with Kartini Kartono's opinion (as cited in Suparyoto, 2011) which states that attention is the concentration of psychic energy directed at an object. In this case it means that parents focus their psychic energy on the child by asking the child's activities and meeting all the children's needs.

The Ministry of Education and Culture of the Republic of Indonesia (2017) suggests that what determines the quality of togetherness is the two-way interaction between parents and children. If the togetherness between parents and children has good qualities, it can lead to stronger emotional bonds between parents and children, children can be open to parents, can train children to get along, and children become happier.

Communication errors that appear in relations between the two respondents are different. One respondent has poor communication with father and another respondent with mother. The responses given by the two respondents tended to be the same, that is, they did not communicate their point of view to their parents. Grotevant \& Cooper (1985: 416) states that children have an awareness of their own perspective and have a sense of responsibility to communicate it clearly with others. The results of this study indicate that respondents lack self-awareness of the affirmation of their perspective to others by communicating clearly.

Conflict between the two respondents with their parents is generally in the form of verbal and physical. The cause of the conflict in this relationship is because the respondent violated a ban that had been given by his parents. This is consistent with the opinion expressed by Thomas (in Laela, 2015) which states that the conflict begins when one party considers the other party to try to derail its interests. When conflicts occur, children tend to feel hurt and angry with their parents, this is consistent with what was stated by Laela (2015) that positive feelings that are built in depth can turn into deep negative feelings as well as conflicts.

In this research, there is a demand to live in accordance with the wishes of parents, live by imitating parents and obey the words of parents who show that in this relationship there are certain rules or orders given by parents to their children. As expressed by Fiske (1992: 691) that in a relationship there is power based on a particular chain that is marked by the action to make rules or govern others (Authority Ranking). In this relationship, parents show the power or authority possessed to the child whose position is under the parent.

Attempts to realize the expectations between parents to children, and children to parents shows that parents and children depend on each other to work together to realize their expectations. In accordance with what was revealed by Fiske (1992: 691) that in a relationship there is an alternating exchange between individuals to get a balance in the relationship. In this relationship, parents and children put their hopes for one another accompanied by various efforts to realize these expectations (Equality Matching). Parents and children are interdependent with each other in an effort to realize their expectations where if the expectations are realized, they benefit each other.

\section{Relationship Dynamics}

Lack of support and communication errors between people know and children cause conflicts in the relationship between parents and children cause conflicts in the relationship. The lack of conflict management efforts in this relationship, accompanied by the influence of internal factors (the development of negative self-identity and low self-control) that causes children to have a tendency to have delinquent behavior. Santrock (2003) states that the factors that cause delinquency in adolescents there are four factors, namely: the formation of negative self-identity in adolescents, adolescent failure to develop self-control, disturbed or lack of family support and inconsistent parent management practices, 


\section{Parent Child Relation in Delinquent Adolescent Nourmarifa Sari ${ }^{1}$, Siti Rohmah Nurhayati ${ }^{2}$}

and the presence of the influence of the surrounding environment and society.

\section{Conclusion and Recommendations}

Conclusion

Based on research that has been done, it can be concluded that relationships according to adolescents who have delinquency behavior are the presence of several things that are positive and negative. Positive relationships include: nurturing, transmitting values, closeness, attention, and togetherness. While negative relationships include lack of support, lack of understanding, miscommunication between parents and children, and conflicts that are not accompanied by good conflict management. Lack of support, lack of understanding and miscommunication between parents and children cause conflict in the relationship. The absence of good conflict management from parents and children to conflicts that arise between them, as well as the influence of internal factors (the development of negative self-identity and low self-control) causes the growth of a tendency to elaborate on children.

\section{Recommendations}

Based on research the following recommendations are given:

For adolescents, build a clear communication of what you actually feel to your parents by using language and intonation that is acceptable to your parents. As well as the condition of your parents whether they are in good condition or not to accept the child's opinion.

For parents, lack of support and understanding from both parents and children can be overcome and prevented through good communication between parents and children. Parents can improve previously poor communication by listening to children's opinions and involving children in joint decision making. Parents should not forbid children to express their opinions and be more open to children.

For further researchers, If researchers want to do the same research, it is suggested to be able to increase the number of research respondents, broaden the age range of respondents and increase the gender variation of research respondents. In collecting data, the researcher is expected to conduct interviews with the respondent's mother as well and be accompanied by observations to the research respondents in order to obtain more detailed and maximum results.

\section{References}

Andayani, F.T. (2017). Peran relasi orang tuaanak dan tekanan teman sebaya terhadap kecenderungan perilaku pengambilan risiko pada remaja di Yogyakarta. Thesis, not published, Universitas Gadjah Mada, Yogyakarta.

Arif, Muhammad Iqbal Syaiful. (2016). Hubungan pola asuh permisif dengan kenakalan remaja. E-Journal UNESA, 6(1), 1-15.

Assifa, F. (24 January 2018). Kepala SMK Kaget Dua Siswanya Bunuh Sopir Taksi "Online". regional.kompas.com.

Badan Pengembangan dan Pembinaan Bahasa. (2016). Kamus Besar Bahasa Indonesia $V$. Jakarta: Kementrian Pendidikan dan Kebudayaan Republik Indonesia.

Brooks, J. (2011). The process of parenting, proses pengasuban edisi kedelapan. (Alih Bahasa: Rahmat Fajar). Yogyakarta: Pustaka Pelajar.

Anonim. (2018, October 22). Balerina Remaja Berprestasi. Retreieved from: mediaindonesia.com.

Dirgagunarsa, Y.S., \& Sutantoputri, N.W. (2004). Hubungan orang tua dan remaja. Jakarta: BPK Gunung Mulia.

Fiske, A.P. (1992). The four elementary forms of sociality: framework for a unified theory of social relations. Psychologichal Review Vol. 99, No. 4, 689-723.

Garvin, G. (2017). Pola asub orangtua dan kecenderungan delinkuensi pada remaja. Jurnal Psikologi Psibernetika Vol. 10, No. 1, 30-39. 


\section{Parent Child Relation in Delinquent Adolescent Nourmarifa Sari ${ }^{1}$, Siti Rohmah Nurhayati ${ }^{2}$}

Grotevant, Harold D. \& Catherine R. Cooper. (1985). Patterns of interaction in family relationship and the development of identity exploration in adolescence. Child Development Vol. 56, No. 2, 415428.

Herdiana, N. (2016). Hubungan antara pola asuh otoriter dengan kenakalan remaja di SMAN 1 Kutupanjang. Skripsi, tidak diterbitkan, Universitas Medan Area, Medan.

Hutapea, E. (26 Februari 2018). Cabuli Pacarnya Saat Bolos Sekolah, Siswa SMP Ini Berurusan dengan Polisi. regional.kompas.com.

Kementerian Kesehatan RI. (2016). Profil kesehatan indonesia tabun 2015. Jakarta: Kementerian Kesehatan RI.

Kementerian Pendidikan dan Kebudayaan RI. (2017). Waktu berkualitas bersama anak. Jakarta: Kementerian Kesehatan RI.

Laela, Faizah Noer. (2015). Bimbingan konseling keluarga dan remaja. Surabaya: UIN Sunan Ampel Press.

Lestari, S. (2014). Psikologi keluarga penanaman nilai dan penanganan konflik dalam keluarga. Jakarta: Kencana Prenada Media Group.

Muqorrobin, A.L.Z. (2016). Pengaruh pola asuh orang tua terhadap kenakalan remaja siswa kelas X dan XI SMKN 2 Malang. Skripsi, tidak diterbitkan, Universitas Islam Negeri Maulana Malik Ibrahim, Malang.

Santrock, J.W. (2003). Adolescence: perkembangan remaja. Jakarta: Erlangga.

Suparyoto, Slamet. (2011). Hubungan perhatian orang tua dengan prestasi belajar siswa kelas V SD Negeri Keputran A Yogyakarta. Skripsi, tidak diterbitkan, Universitas Negeri Yogyakarta, Yogyakarta.

Survei Demografi dan Kesehatan Indonesia. (2013). Kesehatan reproduksi remaja. Jakarta: Badan Pusat Statistik.
Sutrisno, D. (4 January 2016). Anak di bawah Umur Dominasi Pelaku Begal di Makassar. republika.co.id.

Syam, H. (2017). Dinamika keterlibatan remaja menjadi pelaku begal. Thesis, not published, Universitas Gadjah Mada, Yogyakarta.

Widhi, N. (24 May 2017). Inspiratif! 4 Siswa SMA RI Raih Penghargaan Riset Dunia. detik.com.

Widiastuti, N. \& Theresia Widjaja. (2004). Hubungan antara kualitas relasi ayah dengan harga diri remaja putra. Jurnal Psikologi Vol. 2, No. 1, 22-43. 